\title{
Prevalence of Renal Stones Among Patients With Inflammatory Bowel Disease in Saudi Arabia
}

Mahmoud Mosli ${ }^{1}$, Abdulrahman M. Alzahrani ${ }^{1}$, Rafeef A. Bahafzalla ${ }^{2}$, Tala A. Gazzaz ${ }^{2}$, Rahaf M. Slaghour $^{2}$, Ghidah Z. Altabsh ${ }^{2}$, Sarah B. Aljadani ${ }^{2}$, Razan N. Alturkestani ${ }^{2}$, Sondos S. Hussein ${ }^{2}$, Abdullah Kashgary ${ }^{1}$, Omar I. Saadah ${ }^{3}$

1. Department of Internal Medicine, Faculty of Medicine, King Abdulaziz University, Jeddah, SAU 2. Faculty of Medicine, King Abdulaziz University, Jeddah, SAU 3. Department of Pediatrics, Faculty of Medicine, King Abdulaziz University, Jeddah, SAU

Corresponding author: Omar I. Saadah, osaadah@kau.edu.sa

\begin{abstract}
Introduction: Crohn's disease (CD) and ulcerative colitis (UC) are chronic inflammatory bowel diseases (IBD) that affect the gastrointestinal tract with no identified etiology. IBD has been associated with several extraintestinal manifestations (EIMs), including renal involvement such as renal stones (nephrolithiasis), resulting in significant morbidity. This study aims to estimate the prevalence of renal stones among IBD patients in Saudi Arabia.
\end{abstract}

Methods: This is a retrospective study conducted at King Abdulaziz University Hospital between January 2019 and December 2020. All IBD patients with abdominal imaging studies were included in the study regardless of their age. Data were collected from the electronic hospital information system and analyzed.

Results: A total of 363 IBD patients fulfilled the study inclusion criteria. Nephrolithiasis was detected radiologically in $3.6 \%$ of the cohort (5.1\% of UC and $2.7 \%$ of $\mathrm{CD}$ patients). Patients with renal stones are older $(\mathrm{P}=0.002)$ and more likely to be diabetic $(\mathrm{P}=0.047)$, have microscopic hematuria $(\mathrm{P}<0.001)$, and proteinuria $(\mathrm{P}=0.002)$. Binary logistic regression analysis showed that older age at diagnosis $(\mathrm{P}=0.003)$ and microscopic hematuria $(\mathrm{P}=0.02)$ are independent predictors for renal stones.

Conclusion: The study reported that $3.6 \%$ of Saudi IBD patients had renal stones, with a higher prevalence of renal stones formation among UC patients than Crohn's. Older age at diagnosis and the presence of microscopic hematuria may predict the development of renal stones. Future studies should be conducted in a prospective manner at multiple centers across Saudi Arabia for further investigation.

Review began 05/31/2021 Review ended 06/10/2021 Published 06/21/2021

\section{() Copyright 2021}

Mosli et al. This is an open access article distributed under the terms of the Creative Commons Attribution License CC-BY 4.0., which permits unrestricted use, distribution, and reproduction in any medium, provided the original author and source are credited.
Categories: Internal Medicine

Keywords: inflammatory bowel disease, renal stones, nephrolithiasis, prevalence, saudi arabia

\section{Introduction}

Crohn's disease (CD) and ulcerative colitis (UC) are chronic inflammatory bowel diseases (IBD) that affect the gastrointestinal tract with no identified etiology. The pathogeneses of IBD involve a dysregulated immune response to an environmental trigger in individuals with a genetic predisposition [1]. A systematic review that analyzed the global prevalence and incidence of IBD showed high prevalence rates in Europe and North America. Furthermore, the incidence in newly industrialized countries has been rising since 1990 [2]. Saudi Arabia showed a similar rise in IBD incidence, with a higher CD incidence than UC [3,4].

The clinical manifestations of IBD are consequences of ongoing inflammation, which is responsible for the progressive damage of the gastrointestinal tract. Symptoms suggestive of IBD include abdominal pain, diarrhea, rectal bleeding, anemia, fever, and weight loss [5]. IBD also has several extraintestinal manifestations (EIMs) involving the musculoskeletal system (arthritis and ankylosing spondylitis), skin (erythema nodosum, and pyoderma gangrenosum), and the eyes (Iritis and episcleritis). Among the EIMs of IBD, renal stones (nephrolithiasis) may develop in some IBD patients and result in significant morbidity [6]. The prevalence of nephrolithiasis varies between studies, with an estimated prevalence of $3 \%$ to $4.6 \%$ in European countries and up to $38 \%$ in Brazil and South American countries [7,8]. Renal involvement in IBD patients may lead to the development of renal insufficiency, which occurs in approximately $15.9 \%$ of patients [9].

We aim to estimate the prevalence of renal stones among IBD patients in Saudi Arabia, and to identify possible predictors of renal stone formation.

\section{Materials And Methods}

We conducted a hospital-based retrospective study of all patients with a confirmed diagnosis of IBD followed 
up at King Abdulaziz University Hospital (KAUH), Jeddah, Kingdom of Saudi Arabia, between January 2019 and December 2020. All IBD patients, regardless of their age, with reported abdominal ultrasonography (US), abdominal computed tomography (CT), or magnetic resonance imaging (MRI) were included in this study. All radiological reports are reviewed by a radiology consultant specialized in abdominal imaging. Patients' data, including clinical, demographic, and laboratory, were extracted from the medical records. The study was approved by the ethical committee at the Biomedical Ethics Unit at King Abdulaziz University (\#581-19). The study was conducted in agreement with the Declaration of Helsinki.

\section{Outcomes and definitions}

The primary outcome of this study was to measure the prevalence of renal stones (defined as stones detected by US, CT, or MRI in the kidney, renal pelvis, or ureters) in IBD patients. The main secondary outcome of this study is to identify the clinical predictors and the risk factors contributing to the development of renal stones in IBD patients.

\section{Statistical analysis}

Baseline descriptive statistics were calculated for all patients. For continuous variables, means, standard deviations (SDs) were reported, and frequencies for categorical variables. Binary logistic regression analyses were used to identify predictors of primary and secondary outcomes. Odds ratios (OR) and 95\% confidence intervals (CI) were estimated. Statistical Package for the Social Sciences version 26 (IBM Corp., Armonk, NY) was used in our analysis. A p-value of $<0.05$ is considered statistically significant.

\section{Results}

\section{Baseline characteristics}

Totally, 363 patients (224 (6.32\%) with CD and 137 (37.7\%) with UC) who fulfilled the inclusion criteria were included in this study. The median age was 32 years (range, 6-84 years). Females constituted 52.9\% $(n=192)$, and $84.6 \%$ were older than 18 years of age. Associated comorbidities comprising hypertension in $5.5 \%$ and diabetes mellitus in 6.6\%. Details of baseline characteristics are shown in Table 1. 


\section{Cureus}

\begin{tabular}{|c|c|c|c|c|}
\hline Variable & Total $\mathrm{N}=363$ & UC N=137 & CD N=226 & P-value* \\
\hline Age at diagnosis (years), mean $\pm S D$ & $34.78 \pm 15.9$ & $40.1 \pm 18$ & $31.58 \pm 13.6$ & $<0.001^{\star \star}$ \\
\hline \multicolumn{5}{|l|}{ Age category } \\
\hline $0-18$ years & 56 (15.4\%) & 22 (16.1\%) & $34(15 \%)$ & \multirow{2}{*}{0.88} \\
\hline$>18$ years & 307 (84.6\%) & 115 (83.9\%) & 192 (62.3\%) & \\
\hline \multicolumn{5}{|l|}{ Gender } \\
\hline Male & $171(47.1 \%)$ & $59(43.1 \%)$ & $112(49.6 \%)$ & \multirow{2}{*}{0.24} \\
\hline Female & 192 (52.9\%) & 78 (56.9\%) & $114(50.4 \%)$ & \\
\hline \multicolumn{5}{|l|}{ Nationality } \\
\hline Saudi & $246(67.8 \%)$ & 77 (56.2\%) & 169 (74.8\%) & \multirow{2}{*}{$<0.001^{\star *}$} \\
\hline Non-Saudi & 117 (32.2\%) & $60(43.8 \%)$ & $57(25.2 \%)$ & \\
\hline \multicolumn{5}{|l|}{ Hypertension } \\
\hline Yes & 20 (5.5\%) & $6(4.4 \%)$ & $14(6.2 \%)$ & \multirow{2}{*}{0.64} \\
\hline No & 343 (94.5\%) & $131(95.6 \%)$ & 212 (93.8\%) & \\
\hline \multicolumn{5}{|l|}{ Diabetes mellitus } \\
\hline Yes & $24(6.6 \%)$ & $8(5.8 \%)$ & $16(7.1 \%)$ & \multirow{2}{*}{0.83} \\
\hline No & 339 (93.4\%) & $129(94.2 \%)$ & 210 (92.9\%) & \\
\hline Hemoglobin (g/dL) & $11.7 \pm 2.3$ & $11.7 \pm 2.5$ & $11.8 \pm 2.2$ & 0.85 \\
\hline C-reactive protein $(\mathrm{mg} / \mathrm{dL})$ & $22.9 \pm 43.2$ & $25.4 \pm 48.9$ & $21.3 \pm 39.6$ & 0.41 \\
\hline Albumin $(\mathrm{g} / \mathrm{L})$ & $31.4 \pm 7.9$ & $33.2 \pm 7.3$ & $30.3 \pm 8$ & $0.001^{\star \star}$ \\
\hline
\end{tabular}

\section{TABLE 1: Baseline characteristic of the study cohort}

${ }^{\star}$ Chi-square or student t-test.

${ }^{* *} \mathrm{P}<0.05$

\section{Study outcomes}

Of the total cohort, 13 (3.6\%) had renal stones; $5.1 \%$ of UC patients $(n=7)$ and $2.7 \%$ of CD patients $(n=6)$. Stones were detected by the US in nine patients and by CT scan in four patients. It was single in 12 patients and multiple in two other patients. The characteristics of renal stones are shown in Table 2 . 


\section{Cureus}

\begin{tabular}{|c|c|c|c|c|c|c|c|c|}
\hline Number & Gender & $\begin{array}{l}\text { IBD } \\
\text { subtype }\end{array}$ & $\begin{array}{l}\text { Imaging } \\
\text { detection }\end{array}$ & $\begin{array}{l}\text { Stone } \\
\text { numbers }\end{array}$ & $\begin{array}{l}\text { Stone } \\
\text { size }(\mathrm{mm})\end{array}$ & $\begin{array}{l}\text { Stone } \\
\text { location }\end{array}$ & $\begin{array}{l}\text { Associated hydronephrosis } \\
\text { or hydroureter }\end{array}$ & Associated anomalies \\
\hline 1 & M & UC & CT & Single & 2 & $\begin{array}{l}\text { Right } \\
\text { lower pole }\end{array}$ & No & Bilateral renal cysts \\
\hline 2 & $\mathrm{M}$ & UC & US & Single & 7 & $\begin{array}{l}\text { Left lower } \\
\text { pole }\end{array}$ & No & No \\
\hline 3 & $\mathrm{~F}$ & UC & US & Single & 4 & $\begin{array}{l}\text { Left lower } \\
\text { pole }\end{array}$ & No & $\begin{array}{l}\text { Right cortical cyst; left } \\
\text { cortical calcification }\end{array}$ \\
\hline 4 & M & CD & US & Single & 8 & right & No & No \\
\hline 5 & $F$ & $C D$ & CT & Multiple & Tiny & $\begin{array}{l}\text { Left ureter } \\
\text { Renal } \\
\text { bilateral }\end{array}$ & $\begin{array}{l}\text { Mild hydroureter and } \\
\text { hydronephrosis }\end{array}$ & No \\
\hline 6 & $\mathrm{~F}$ & CD & US & Single & 8 & $\begin{array}{l}\text { Right } \\
\text { lower pole }\end{array}$ & No & No \\
\hline 7 & $\mathrm{~F}$ & UC & CT & Multiple & Tiny & $\begin{array}{l}\text { Bilateral } \\
\text { renal }\end{array}$ & No & Bilateral simple renal cysts \\
\hline 8 & $M$ & UC & CT & Single & 8 & $\begin{array}{l}\text { Left lower } \\
\text { pole }\end{array}$ & No & Right renal cyst \\
\hline 9 & $\mathrm{~F}$ & CD & US & Single & 3.6 & $\begin{array}{l}\text { Right } \\
\text { renal }\end{array}$ & No & No \\
\hline 10 & $\mathrm{~F}$ & UC & US & Single & 3.2 & $\begin{array}{l}\text { Left mid } \\
\text { pole }\end{array}$ & No & No \\
\hline 11 & $\mathrm{~F}$ & CD & US & Single & 6 & $\begin{array}{l}\text { Left upper } \\
\text { pole }\end{array}$ & Slight calyceal fullness & No \\
\hline 12 & M & UC & US & Single & 4 & $\begin{array}{l}\text { Right } \\
\text { lower pole }\end{array}$ & No & No \\
\hline 13 & $\mathrm{~F}$ & $C D$ & US & Single & 8 & $\begin{array}{l}\text { Rt upper } \\
\text { pole }\end{array}$ & No & No \\
\hline
\end{tabular}

TABLE 2: The characteristics of the inflammatory bowel disease patients with renal stones

CD: Crohn's disease, UC: ulcerative colitis, US: ultrasonography.

Comparing patients with and without renal stones (Table 3) revealed that patients with renal stones are older $(\mathrm{P}=0.002)$, had more DM $(\mathrm{P}=0.047)$, and more likely to have microscopic hematuria $(\mathrm{P}=0.002)$ and proteinuria $(0.002)$ in urinary examinations.

\begin{tabular}{|c|c|c|c|}
\hline Variables & Renal stone $\mathrm{N}=13 \mathrm{~N}(\%)$ or mean $\pm \mathrm{SD}$ & No renal stone $\mathrm{N}=350 \mathrm{~N}(\%)$ or mean $\pm \mathrm{SD}$ & P-value* \\
\hline Age at diagnosis (years) & $48.5 \pm 16.7$ & $34.3 \pm 15.7$ & 0.002 \\
\hline \multicolumn{4}{|l|}{ Gender } \\
\hline Male & 5 (38.5\%) & 166 (47.4\%) & 0.58 \\
\hline Female & $8(61.5 \%)$ & $184(52.6 \%)$ & \\
\hline \multicolumn{4}{|l|}{ IBD subtypes } \\
\hline CD & $6(46.2 \%)$ & $220(62.9 \%)$ & 0.25 \\
\hline UC & $7(53.8 \%)$ & 130 (37.1\%) & \\
\hline
\end{tabular}




\section{Cureus}

\begin{tabular}{|c|c|c|c|}
\hline Saudi & $8(61.5 \%)$ & 238 (68\%) & 0.76 \\
\hline Non-Saudi & $5(38.5 \%)$ & & \\
\hline \multicolumn{4}{|c|}{ Chronic kidney disease } \\
\hline Yes & $0(0.0 \%)$ & $3(0.9 \%)$ & 1.0 \\
\hline No & $13(100 \%)$ & 347 (99.1\%) & \\
\hline \multicolumn{4}{|l|}{ Diabetes mellitus } \\
\hline Yes & $3(23.1 \%)$ & $21(6 \%)$ & $0.047^{\star \star}$ \\
\hline No & 10 (76.9\%) & 329 (94\%) & \\
\hline \multicolumn{4}{|l|}{ Hypertension } \\
\hline Yes & $18(5.1 \%)$ & 2 (15.4\%) & 0.16 \\
\hline No & $332(94.9 \%)$ & $11(84.6 \%)$ & \\
\hline \multicolumn{4}{|l|}{ Renal malignancy } \\
\hline Yes & $1(7.7 \%)$ & $1(0.3 \%)$ & 0.07 \\
\hline No & $12(92.3 \%)$ & 349 (99.7\%) & \\
\hline \multicolumn{4}{|c|}{ Microscopic hematuria } \\
\hline Positive & 9 (69.2\%) & $56(16 \%)$ & $<0.001^{\star *}$ \\
\hline Negative & $4(30.8 \%)$ & $294(84 \%)$ & \\
\hline \multicolumn{4}{|l|}{ Proteinuria } \\
\hline Positive & $6(50 \%)$ & $42(12 \%)$ & $0.002^{\star \star}$ \\
\hline Negative & $6(50 \%)$ & 308 (88\%) & \\
\hline \multicolumn{4}{|l|}{ Fistula } \\
\hline Yes & $1(7.7 \%)$ & $36(10.3 \%)$ & 1.0 \\
\hline No & $12(92.3 \%)$ & $314(89.7 \%)$ & \\
\hline CRP (mg/dL) & $10.8 \pm 10.2$ & $23.2 \pm 43.9$ & 0.37 \\
\hline $\mathrm{ESR}(\mathrm{mm} / \mathrm{H})$ & $35.4 \pm 34.5$ & $28.5 \pm 25.2$ & 0.48 \\
\hline Creatinine $(\mu \mathrm{mol} / \mathrm{L})$ & $72.6 \pm 27.8$ & $64.5 \pm 27.7$ & 0.31 \\
\hline $\mathrm{Hb}(\mathrm{g} / \mathrm{dL})$ & $12.5 \pm 2.4$ & $11.7 \pm 2.3$ & 0.25 \\
\hline Albumin (g/L) & $33.2 \pm 7.5$ & $31.4 \pm 7.8$ & 0.41 \\
\hline
\end{tabular}

\section{TABLE 3: Comparing patients with and without renal stones}

${ }^{*}$ Chi-square, Fisher's exact, or student t-test.

${ }^{* *} \mathrm{P}<0.05$

Binary logistic regression analysis identified older age at diagnosis $(\mathrm{P}=0.003)$ and the presence of microscopic hematuria $(\mathrm{P}=0.016)$ as predictors for renal stones (Table 4). 


\section{Cureus}

\begin{tabular}{|c|c|c|c|c|c|c|}
\hline \multirow{2}{*}{ Variable } & \multirow{2}{*}{ B } & \multirow{2}{*}{ SE } & \multirow{2}{*}{$O R$} & \multicolumn{2}{|c|}{$95 \% \mathrm{Cl}$ for OR } & \multirow{2}{*}{ P-value } \\
\hline & & & & Lower & Upper & \\
\hline Age at diagnosis (years) & 0.058 & 0.019 & 1.06 & 1.02 & 1.10 & $0.003^{\star}$ \\
\hline Diabetes mellitus & 0.743 & 0.91 & 2.10 & 0.35 & 12.53 & 0.41 \\
\hline Microscopic hematuria & 1.836 & 0.77 & 6.27 & 1.39 & 28.12 & $0.02^{\star}$ \\
\hline Proteinuria & 1.330 & 0.78 & 3.78 & 0.81 & 17.55 & 0.09 \\
\hline
\end{tabular}

TABLE 4: Binary logistic regression analysis of possible predictors of renal stones

${ }^{\star} \mathrm{P}<0.05$.

OR: odds ratio.

\section{Discussion}

This study estimated the prevalence of renal stones among IBD patients in a single tertiary care center in Jeddah, Saudi Arabia. Renal involvement is considered one of the rare EIMs of IBD, which occurs in 4-23\% of patients [10]. In addition, renal involvement in IBD may negatively impact the patient's quality of life [11]. The current study estimated that $3.6 \%$ of IBD patients have renal stones, which is lower than the prevalence rate reported in the United States of 12-28\% [12]. This variation could be attributed to differences in the disease severity of the population studied and the methods of detection. In severe disease, the amount of extracellular fluid loss due to diarrhea and malabsorption may contribute to the development of renal stones $[13,14]$. Our results showed a higher prevalence of renal stone formation among UC patients compared to $\mathrm{CD}$ (5.1\% vs. 2.7\%). This result is different from the findings of previously reported studies of a higher prevalence of renal stones in CD patients than in UC [7,14-17]. Studies reported increased risk in UC patients after Ileoanal pouch anastomosis $[18,19]$. This may be attributed to the crystallized precipitation of mesalazine - a commonly used medication for UC - as reported in the literature [20-24].

In the present study, we found no gender influence on renal stone formation among IBD patients. This finding is in accordance with the results of another study from the United Kingdom [14]. Other studies have reported male predominance in both UC and CD [7], and in CD only [25]. Older age at diagnosis, DM, and microscopic hematuria were identified as possible predictors for renal stones formation. Previous studies have reported the association of DM with nephrolithiasis [26-28]. Therefore, the coexistence of DM and IBD may increase the risk of developing renal stones. We also found microscopic hematuria among the predictors for the development of renal stones. This may result from local tissue damage owing to the presence of renal stones [29] or may be considered as an EIMs of IBD per se, as previously reported [30]. We did not find proteinuria as a predictor for renal stone formation. It rather reflects other renal pathology such as tubulointerstitial nephritis [31-38].

The study may be limited by its retrospective nature, lack of control group, and a lack of long-term followup, but sheds significant light on the occurrence of renal stones in Saudi patients with IBD patients that may add more to their existing morbidity.

\section{Conclusions}

Nephrolithiasis is known as one of the EIM of IBD. The study showed that $3.6 \%$ of Saudi IBD patients had nephrolithiasis with high prevalence of renal stone formation among UC patients compared to CD. Older age at diagnosis and microscopic hematuria were identified as predictors for developing kidney stones. While other factors were not found to be predictors, future studies should be conducted in a prospective manner at multiple centers across Saudi Arabia for further investigation.

\section{Additional Information \\ Disclosures}

Human subjects: Consent was obtained or waived by all participants in this study. Ethical Committee at the Biomedical Ethics Unit at King Abdulaziz University issued approval \#581-19. Animal subjects: All authors have confirmed that this study did not involve animal subjects or tissue. Conflicts of interest: In compliance with the ICMJE uniform disclosure form, all authors declare the following: Payment/services info: All authors have declared that no financial support was received from any organization for the submitted work. Financial relationships: All authors have declared that they have no financial relationships at present or within the previous three years with any organizations that might have an 
interest in the submitted work. Other relationships: All authors have declared that there are no other relationships or activities that could appear to have influenced the submitted work.

\section{References}

1. Danese S, Fiocchi C: Etiopathogenesis of inflammatory bowel diseases. World J Gastroenterol. 2006, 12:4807-12. 10.3748/wjg.v12.i30.4807

2. Ng SC, Shi HY, Hamidi N, et al.: Worldwide incidence and prevalence of inflammatory bowel disease in the 21st century: a systematic review of population-based studies. Lancet. 2018, 390:2769-78. 10.1016/s01406736(17)32448-0

3. Al-Mofarreh MA, Al-Mofleh IA: Emerging inflammatory bowel disease in saudi outpatients: a report of 693 cases. Saudi J Gastroenterol. 2013, 19:16-22. 10.4103/1319-3767.105915

4. Khawaja AQ, Sawan AS: Inflammatory bowel disease in the Western Saudi Arabia . Saudi Med J. 2009, 30:537-40.

5. Wang YF, Zhang H, Ouyang Q: Clinical manifestations of inflammatory bowel disease: East and West differences. J Dig Dis. 2007, 8:121-7. 10.1111/j.1443-9573.2007.00296.x

6. Greenstein AJ, Janowitz HD, Sachar DB: The extra-intestinal complications of Crohn's disease and ulcerative colitis: a study of 700 patients. Medicine (Baltimore). 1976, 55:401-12. 10.1097/00005792-197609000-00004

7. Fagagnini S, Heinrich H, Rossel JB, et al.: Risk factors for gallstones and kidney stones in a cohort of patients with inflammatory bowel diseases. PLoS One. 2017, 12:e0185193. 10.1371/journal.pone.0185193

8. Cury DB, Moss AC, Schor N: Nephrolithiasis in patients with inflammatory bowel disease in the community . Int J Nephrol Renovasc Dis. 2013, 6:139-42. 10.2147/IJNRD.S45466

9. Lewis B, Mukewar S, Lopez R, Brzezinski A, Hall P, Shen B: Frequency and risk factors of renal insufficiency in inflammatory bowel disease inpatients. Inflamm Bowel Dis. 2013, 19:1846-51. 10.1097/MIB.0b013e31828a661e

10. Park S, Chun J, Han KD, et al.: Increased end-stage renal disease risk in patients with inflammatory bowel disease: a nationwide population-based study. World J Gastroenterol. 2018, 24:4798-808. 10.3748/wjg.v24.i42.4798

11. Pardi DS, Tremaine WJ, Sandborn WJ, McCarthy JT: Renal and urologic complications of inflammatory bowel disease. Am J Gastroenterol. 1998, 93:504-14. 10.1111/j.1572-0241.1998.156_b.x

12. Rothfuss KS, Stange EF, Herrlinger KR: Extraintestinal manifestations and complications in inflammatory bowel diseases. World J Gastroenterol. 2006, 12:4819-31. 10.3748/wig.v12.i30.4819

13. Oikonomou K, Kapsoritakis A, Eleftheriadis T, Stefanidis I, Potamianos S: Renal manifestations and complications of inflammatory bowel disease. Inflamm Bowel Dis. 2011, 17:1034-45. 10.1002/ibd.21468

14. Parks JH, Worcester EM, O'Connor RC, Coe FL: Urine stone risk factors in nephrolithiasis patients with and without bowel disease. Kidney Int. 2003, 63:255-65. 10.1046/j.1523-1755.2003.00725.x

15. McConnell N, Campbell S, Gillanders I, Rolton H, Danesh B: Risk factors for developing renal stones in inflammatory bowel disease. BJU Int. 2002, 89:835-41. 10.1046/j.1464-410x.2002.02739.x

16. Caudarella R, Rizzoli E, Pironi L, et al.: Renal stone formation in patients with inflammatory bowel disease . Scanning Microsc. 1993, 7:371.

17. Deren JJ, Porush JG, Levitt MF, Khilnani MT: Nephrolithiasis as a complication of ulcerative colitis and regional enteritis. Ann Intern Med. 1962, 56:843-53. 10.7326/0003-4819-56-6-843

18. Arora Z, Mukewar S, Lopez R, Camino D, Shen B, Hall P: Etiopathogenesis of nephrolithiasis in ulcerative colitis patients with the ileal pouch anal anastomosis. Inflamm Bowel Dis. 2017, 23:840-6. 10.1097/MIB.0000000000001070

19. Mukewar S, Hall P, Lashner BA, Lopez R, Kiran RP, Shen B: Risk factors for nephrolithiasis in patients with ileal pouches. J Crohns Colitis. 2013, 7:70-8. 10.1016/j.crohns.2012.05.006

20. von Arnim U, Peitz U, Vinson B, Gundermann KJ, Malfertheiner P: STW 5, a phytopharmacon for patients with functional dyspepsia: results of a multicenter, placebo-controlled double-blind study. Am J Gastroenterol. 2007, 102:1268-75. 10.1111/j.1572-0241.2006.01183.x

21. Sáez-González E, Conde I, Díaz-Jaime FC, Benlloch S, Prieto M, Berenguer M: Iberogast-induced severe hepatotoxicity leading to liver transplantation. Am J Gastroenterol. 2016, 111:1364-5. 10.1038/ajg.2016.260

22. Jacobsson H, Eriksen J, Karlén P: Mesalazine-induced renal calculi. Am J Case Rep. 2013, 14:551-3. 10.12659/AJCR.889719

23. Corbery B, Lebdai S, Borojeni S, Bigot P, Azzouzi AR, Culty T: Mesalazine: a novel etiology for drug-induced urinary calculi. Urol J. 2018, 15:132-3. 10.22037/uj.v0i0.3902

24. Simsek M, de Boer NKH: Mesalazine and nephrolithiasis: leave no stone unturned. Am J Gastroenterol. 2019, 114:1359-60. 10.14309/ajg.0000000000000311

25. Gelzayd EA, Breuer RI, Kirsner JB: Nephrolithiasis in inflammatory bowel disease. Am J Dig Dis. 1968, 13:1027-34. 10.1007/BF02233547

26. Lieske JC, de la Vega LS, Gettman MT, Slezak JM, Bergstralh EJ, Melton LJ III, Leibson CL: Diabetes mellitus and the risk of urinary tract stones: a population-based case-control study. Am J Kidney Dis. 2006, 48:897904. 10.1053/j.ajkd.2006.09.002

27. Pak CY, Sakhaee K, Moe O, et al.: Biochemical profile of stone-forming patients with diabetes mellitus . Urology. 2003, 61:523-7. 10.1016/s0090-4295(02)02421-4

28. Daudon M, Traxer O, Conort P, Lacour B, Jungers P: Type 2 diabetes increases the risk for uric acid stones . I Am Soc Nephrol. 2006, 17:2026-33. 10.1681/ASN.2006030262

29. Larsen S, Bendtzen K, Nielsen OH: Extraintestinal manifestations of inflammatory bowel disease: epidemiology, diagnosis, and management. Ann Med. 2010, 42:97-114. 10.3109/07853890903559724

30. Velciov S, Gluhovschi G, Sporea I, et al.: Asymptomatic urinary anomalies, hematuria and proteinuria, in patients with inflammatory bowel disease. Preliminary study. Rom J Intern Med. 2011, 49:113-20.

31. Fraser JS, Muller AF, Smith DJ, Newman DJ, Lamb EJ: Renal tubular injury is present in acute inflammatory bowel disease prior to the introduction of drug therapy. Aliment Pharmacol Ther. 2001, 15:1131-7.

10.1046/j.1365-2036.2001.01041.x 


\section{Cureus}

32. Mahmud N, O'Toole D, O'Hare N, Freyne PJ, Weir DG, Kelleher D: Evaluation of renal function following treatment with 5-aminosalicylic acid derivatives in patients with ulcerative colitis. Aliment Pharmacol Ther. 2002, 16:207-15. 10.1046/j.1365-2036.2002.01155.x

33. Poulou AC, Goumas KE, Dandakis DC, et al.: Microproteinuria in patients with inflammatory bowel disease: is it associated with the disease activity or the treatment with 5-aminosalicylic acid?. World J Gastroenterol. 2006, 12:739-46. 10.3748/wjg.v12.i5.739

34. Marcus SB, Brown JB, Melin-Aldana H, Strople JA: Tubulointerstitial nephritis: an extraintestinal manifestation of Crohn disease in children. J Pediatr Gastroenterol Nutr. 2008, 46:338-41. 10.1097/MPG.0b013e31806dc2c4

35. Izzedine H, Simon J, Piette AM, et al.: Primary chronic interstitial nephritis in Crohn's disease . Gastroenterology. 2002, 123:1436-40. 10.1053/gast.2002.36613

36. Kreisel W, Wolf LM, Grotz W, Grieshaber M: Renal tubular damage: an extraintestinal manifestation of chronic inflammatory bowel disease. Eur J Gastroenterol Hepatol. 1996, 8:461-8.

37. Herrlinger KR, Noftz MK, Fellermann K, Schmidt K, Steinhoff J, Stange EF: Minimal renal dysfunction in inflammatory bowel disease is related to disease activity but not to 5-ASA use. Aliment Pharmacol Ther. 2001, 15:363-9. 10.1046/j.1365-2036.2001.00940.x

38. Mahmud N, McDonald GS, Kelleher D, Weir DG: Microalbuminuria correlates with intestinal histopathological grading in patients with inflammatory bowel disease. Gut. 1996, 38:99-103. 10.1136/gut.38.1.99 